This document was prepared in conjunction with work accomplished under Contract No. DE-AC09-96SR18500 with the U. S. Department of Energy.

\title{
DISCLAIMER
}

This report was prepared as an account of work sponsored by an agency of the United States Government. Neither the United States Government nor any agency thereof, nor any of their employees, nor any of their contractors, subcontractors or their employees, makes any warranty, express or implied, or assumes any legal liability or responsibility for the accuracy, completeness, or any third party's use or the results of such use of any information, apparatus, product, or process disclosed, or represents that its use would not infringe privately owned rights. Reference herein to any specific commercial product, process, or service by trade name, trademark, manufacturer, or otherwise, does not necessarily constitute or imply its endorsement, recommendation, or favoring by the United States Government or any agency thereof or its contractors or subcontractors. The views and opinions of authors expressed herein do not necessarily state or reflect those of the United States Government or any agency thereof. 
Key Words:

Tank $48 H$

Cesium

Tetraphenylborate

Retention: Permanent

\section{TASK TECHNICAL AND QUALITY ASSURANCE PLAN FOR THE CHARACTERIZATION AND LEACHING OF A THERMOWELL AND CONDUCTIVITY PROBE PIPE SAMPLE FROM TANK 48H}

F. F. Fondeur

W. R. Wilmarth

November 2, 2005

Westinghouse Savannah River Company

Savannah River Site

Aiken, SC 29808

Prepared for the U. S. Department of Energy Under

Contract Number DE-AC09-96SR18500

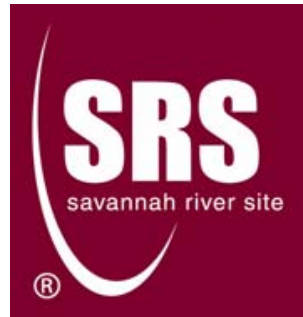


WSRC-TR-2005-00193

Page 2 of 12

\section{$\underline{\text { AUTHORS }}$}

\section{REVIEWS AND APPROVALS}



\section{APPROVALS}
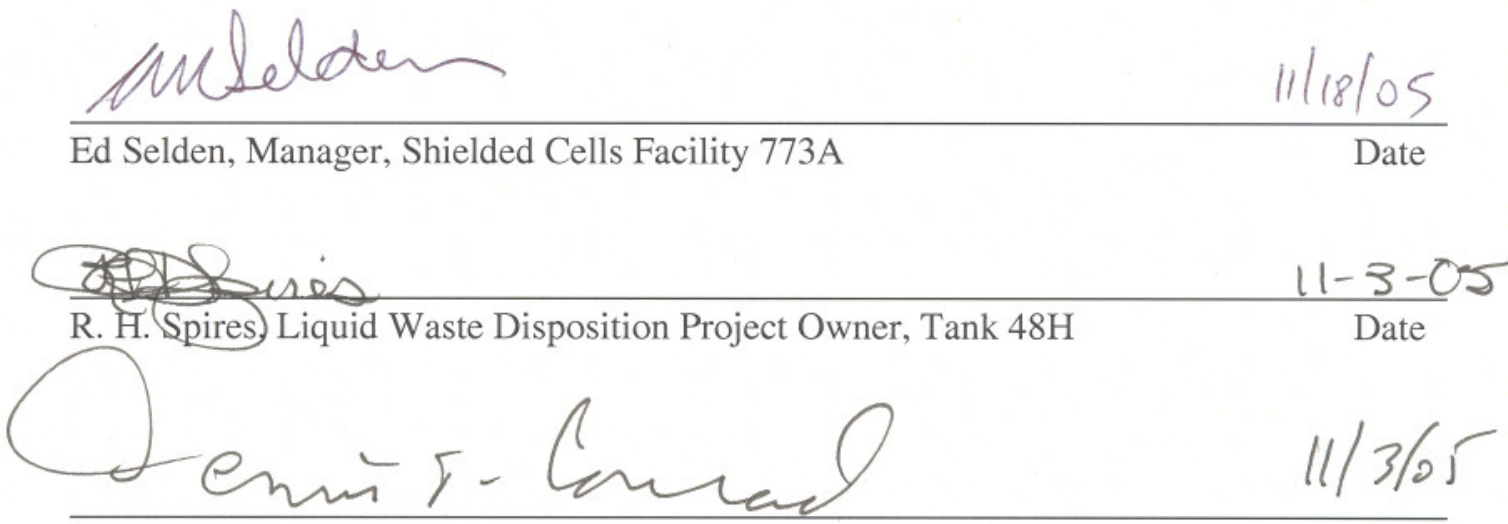

D. T. Conrad, Manager, Low Curie Salt Engineering

Date

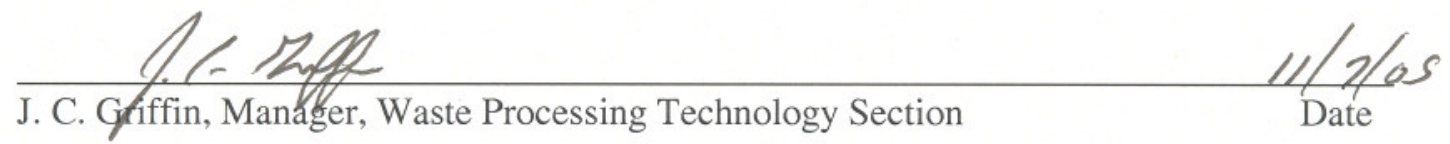


WSRC-TR-2005-00193

Page 3 of 12

List of Abbreviations

$\begin{array}{ll}\text { ADS } & \text { Analytical Development Section } \\ \text { HPLC } & \text { High Performance Liquid Chromatography } \\ \text { ICP-OES } & \text { Inductively Coupled Plasma - Optical Emissions Spectroscopy } \\ \text { ICA } & \text { Ion Chromatography for Anions Analysis } \\ \text { VOA } & \text { Volatile Analysis (for example benzene) } \\ \text { SVOA } & \text { Semi-Volatile Analysis } \\ \text { SRNL } & \text { Savannah River National Laboratory } \\ \text { SPF } & \text { Saltstone Production Facility } \\ \text { SWPF } & \text { Salt Waste Processing Facility } \\ \text { WPTS } & \text { Waste Processing Technology Section } \\ \text { DWPF } & \text { Defense Waste Processing Facility } \\ \text { SC } & \text { Shielded Cells Facility }\end{array}$


WSRC-TR-2005-00193

Page 4 of 12

\section{Executive Summary}

A key component for the accelerated implementation and operation of the Salt Waste Processing Facility (SWPF) is the recovery of Tank $48 \mathrm{H}$. Tank $48 \mathrm{H}$ is a type IIIA tank with a maximum capacity of 1.3 million gallons. The material on the Tank $48 \mathrm{H}$ internal tank surfaces is estimated to have a total volume of approximately 115 gallons consisting of mostly water soluble solids with approximately $20 \mathrm{wt} \%$ insoluble solids (33 $\mathrm{Kg}$ TPB). ${ }^{1}$ This film is assumed to be readily removable.

The material on the internal equipment/surfaces of Tank $48 \mathrm{H}$ is presumed to be easily removed by slurry pump operation. For Tank $49 \mathrm{H}$, the slurry pumps were operated almost continuously for approximately 6 months after which time the tank was inspected and the film was found to be removed. The major components of the Tank $49 \mathrm{H}$ film were soluble solids $-\mathrm{Na}_{3} \mathrm{H}(\mathrm{CO})_{2}, \mathrm{Al}(\mathrm{OH})_{3}, \mathrm{NaTPB}, \mathrm{NaNO}_{3}$ and $\mathrm{NaNO}_{2}{ }^{2}$. Although the Tank $48 \mathrm{H}$ film is expected to be primarily soluble solids, it may not behave the same as the Tank $49 \mathrm{H}$ film. Depending on when the Recycle material or inhibited water can be added to Tank $48 \mathrm{H}$, the tank may not be allowed to agitate for this same amount of time. The tank will be filled above 150 inches and agitated at least once during the Aggregation process. If the material cannot be removed after completion of these batches, the material may be removed with additional fill and agitation operations. There is a risk that this will not remove the material from the internal surfaces. As a risk mitigation activity, properties of the film and the ease of removing the film from the tank will be evaluated prior to initiating Aggregation.

This task will investigate the dissolution of Tank 48H solid deposits in inhibited water and DWPF recycle. To this end, tank personnel plan to cut and remove a thermowell pipe from Tank $48 \mathrm{H}$ and submit the cut pieces to SRNL for both characterization and leaching behavior. A plan for the removal, packaging and transport of the thermowell pipe has been issued. ${ }^{3}$ This task plan outlines the proposed method of analysis and testing to estimate 1) the thickness of the solid deposit, 2) chemical composition of the deposits and 3) the leaching behavior of the solid deposits in inhibited water (IW) and in Tank $48 \mathrm{H}$ aggregate solution. ${ }^{4}$

\section{Task Description}

Plant personnel plan to remove a thermowell and conductivity probe pipe from Riser D2 in Tank 48H. The thermowell is a schedule 40 stainless steel pipe (internal diameter equals one inch). Plant personnel will remove four sections of approximately 24" each from the region of 76" to 124" above the bottom of the tank. Plant labeled each cut as “1”, “2”, “3”, and " 4 ”. Figure 1 shows a caricature of the thermowell and conductivity probe pipe and their labeled cuts. Plant personnel will then send the four long pipe sections to SRNL. Each of the four pipes will be labeled with a tagged wire. Unused pipes (scrapped pipe not used in the leaching study) in this study will be archived in a non-transparent cylindrical container (like those used for storing maps). The estimated solid deposit thickness on the pipe is about 1 millimeter. Each pipe is estimated to contain 0.03 grams of solids per inch (2.88 grams total available). The estimated dry 
WSRC-TR-2005-00193

Page 5 of 12

solid concentration is $20 \mathrm{wt} \%$. Shielded cell (SC) personnel have received and placed the pipes in cell \#3 in A-block section of the cells.

\section{Pipe Selection for the Different Tests}

The pipes will not receive additional cutting. Table 1 shows the pipes selected for the different actions or steps to be taken in the task.

Thermowell and conductivity probe

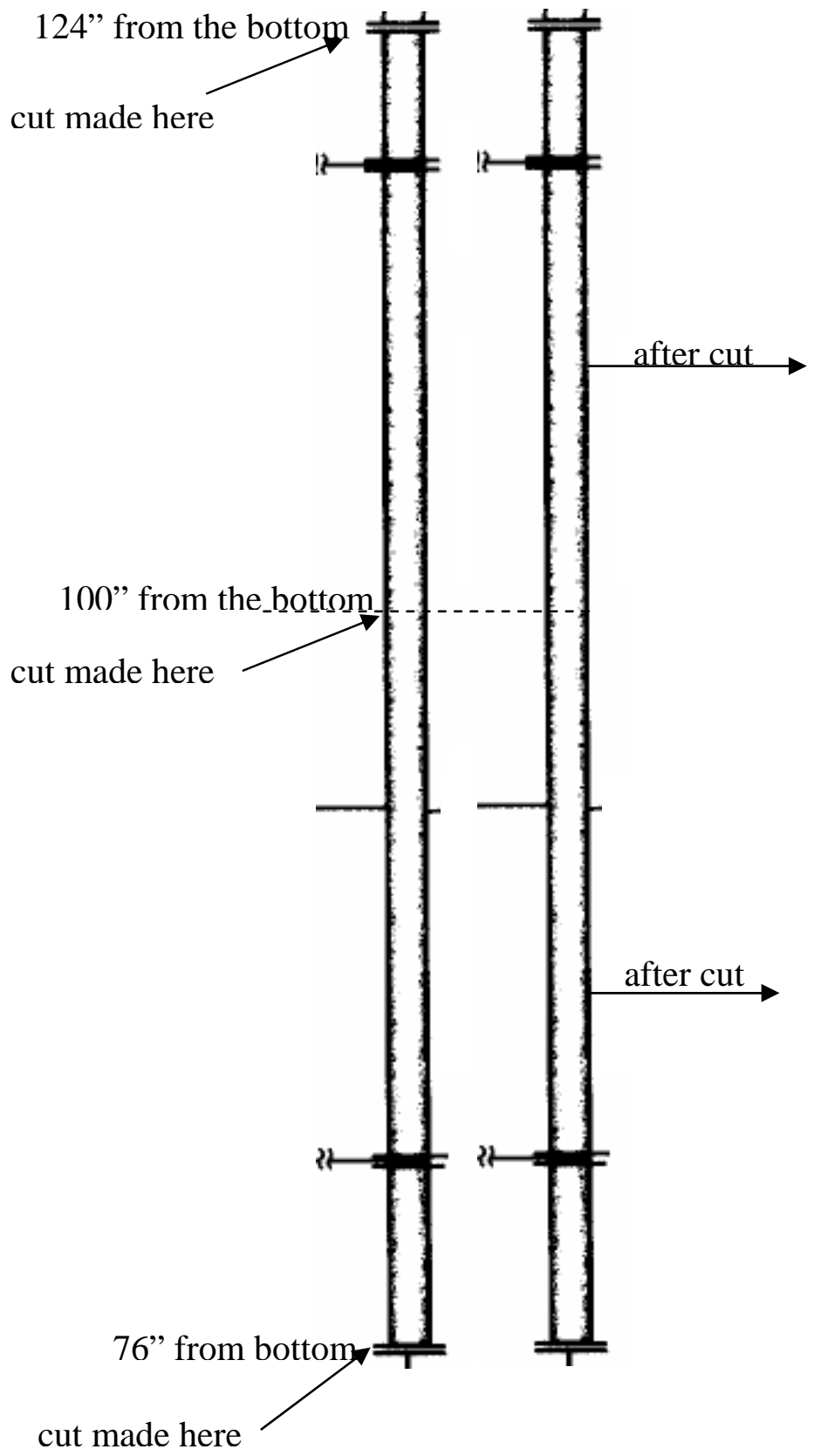

Cut sections sent to SRNL
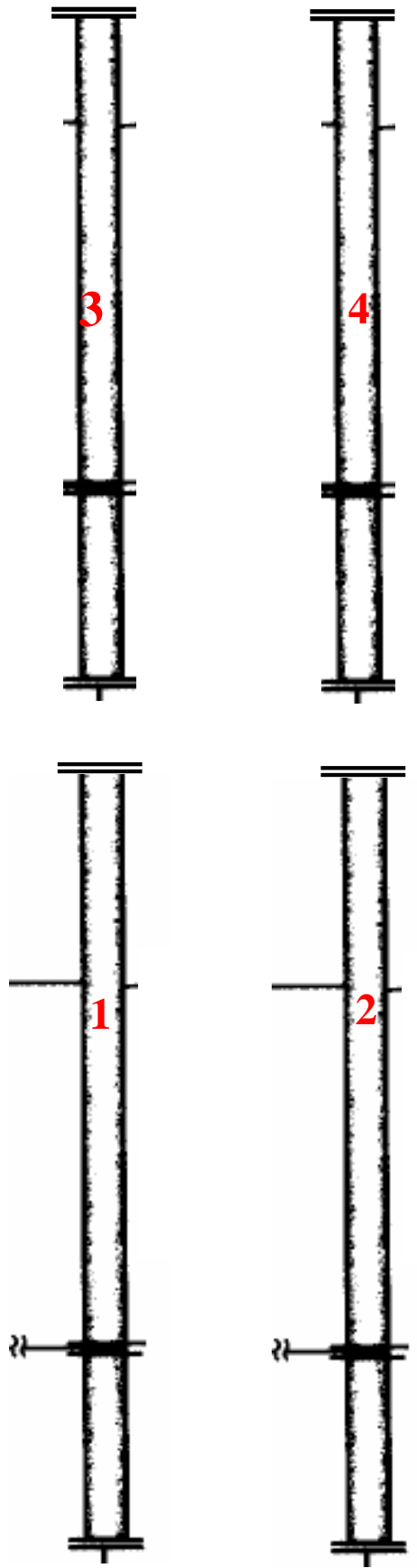

Figure 1. Schematic of the cut sections from the thermowell and conductivity pipes 
WSRC-TR-2005-00193

Page 6 of 12

Table 1. Pipe assignment to the different jobs in this task plan.

\begin{tabular}{|c|c|}
\hline Test & Pipe label \\
\hline Leaching in Inhibited water & 3 \\
\hline $\begin{array}{c}\text { Leaching in Tank 48H } \\
\text { aggregate }\end{array}$ & 4 \\
\hline $\begin{array}{c}\text { Deposit Characterization: } \\
\text { extraction (with acetonitrile } \\
\text { followed by water) }\end{array}$ & $1,2,3$, and 4 \\
\hline $\begin{array}{c}\text { Deposit Characterization: } \\
\text { Digestion (insolubles) }\end{array}$ & $1,2,3$, and 4 \\
\hline $\begin{array}{c}\text { Solid Deposit Thickness } \\
\text { Determination }\end{array}$ & $1,2,3$, and 4 \\
\hline
\end{tabular}

\section{Determination of Solid Deposit Thickness}

Plant personnel estimated the solid deposit thickness to be approximately $1 \mathrm{~mm}$ thick. ${ }^{1}$ On the thermowell, this represents about $30 \mathrm{mg}$ of solids per inch of pipe. For a 24 inch long pipe, the total solid deposit amount expected is 720 milligrams. Assuming all of the solid deposit is removed from the pipe, the net weight loss (pipe with solids minus the bare pipe) is $0.4 \mathrm{wt} \%$. This weight loss is not within the accuracy of the balance currently used in the SC facility. Therefore, direct gravimetric measurements of the pipes cannot be considered further. Scrapping a known area and weighing the removed solids is the recommended method. ${ }^{5}$ The balances in the Shielded Cells are accurate to within 30 milligrams. Therefore, to minimize gravimetric errors in the calculation we need to scrape off five inches wide ring around each pipe. The removed deposits will be weighed and the four calculated thicknesses will be compared and averaged. The removed deposits will then be composite and submitted for characterization as described in Section 5 below.

\section{Solid Deposit Characterization}

The analytical aim of this section is to determine the fate of the phenyl borates, cesium, insolubles (i.e. sludge and MST) and the anions. We eliminated Free $\mathrm{OH}$, Total Organic and Inorganic analysis from consideration. From the mass balance, we can account for the amounts of $\mathrm{NaOH}$ solids on the pipes. 


\subsection{TPB and Degradation Products Determination: HPLC}

About $30 \mathrm{mg}$ of samples will be submitted to ADS for HPLC analysis. ADS plans to contact the solids with $10 \mathrm{~mL}$ of acetonitrile to extract TPB and its degradation products. The solid deposits will be dropped into $10 \mathrm{~mL}$ of acetonitrile solvent. Initially, the bottle will shake for 24 hours after which the bottle will be allowed to settle for 20 minutes. About $100 \mu \mathrm{L}$ of solvent will be removed from the bottle and injected to the HPLC unit. The analysis plan summary for this task is listed in Table 2. A list of the detection limits for each analytical method is shown in Table 3. Please note that many of the analysis will be done on small quantities of samples (30 mg) and that analytical and facility personnel are aware that they have only one opportunity to sample and analyze in this experiment (we will archive two pipes for future tests or analysis). The lack of duplicate samples will also affect the statistics calculated for the results. For example, both precision and accuracy values may not be determined.

\subsection{Metal and Anion Determination: ICP-OES and IC-Anion Analysis}

In order to determine the anion content of the solids, $30 \mathrm{mg}$ of removed deposits will be mixed with $1.5 \mathrm{ml}$ of deionized and distilled water. The resulting solution will be passed through an ion chromatography column. ADS personnel will conduct the separation and concentration analysis. The analysis plan for this task is listed in Table 2. For gamma radiation determination, $30 \mathrm{mg}$ of sample will be removed from the cells and counted by ADS personnel.

Table 2. Required sample inventory for the analysis of the solid deposits on the thermowell pipe.

\begin{tabular}{|c|c|c|c|c|c|}
\hline Analysis & $\begin{array}{l}\text { Number of } \\
\text { Samples }\end{array}$ & $\begin{array}{c}\text { Sample } \\
\text { Volume, } \\
\text { mg }\end{array}$ & $\begin{array}{c}\text { Dilution } \\
\text { Volume, } \mathrm{mL}\end{array}$ & Diluent & $\begin{array}{l}\text { Inches of } \\
\text { Pipe for } \\
\text { Scrapping }\end{array}$ \\
\hline $\begin{array}{l}\text { HPLC (TPB, 3PB, 2PB, PB, } \\
\text { Phenol) }\end{array}$ & 1 & 30 & 2 & $\begin{array}{l}\text { Extraction with } \\
\text { Acetonitrile }\end{array}$ & 5 \\
\hline $\begin{array}{l}\text { IC ANIONS [F', } \mathrm{Cl}^{-}, \mathrm{HCO}_{2}^{-}, \\
\left(\mathrm{C}_{2} \mathrm{O}_{4}\right)_{2}^{-}, \quad\left(\mathrm{SO}_{4}\right)_{2}^{-}, \\
\mathrm{PO}_{4}{ }^{3-}, \\
\left.\left(\mathrm{NO}_{3}\right)^{-},\left(\mathrm{NO}_{2}\right)^{-}\right],\end{array}$ & 1 & 30 & 1.5 & $\begin{array}{l}\text { Extraction with } \\
\qquad \mathrm{H}_{2} \mathrm{O}\end{array}$ & 5 \\
\hline ICP-OES & 1 & 30 & 0 & $\begin{array}{l}\text { Digested with } \\
\mathrm{HCl}, \mathrm{HF} \text { and } \\
\mathrm{HNO}_{3}\end{array}$ & 5 \\
\hline GAMMA SPEC (Cs-137) & 1 & 30 & 0 & None & 5 \\
\hline Total & 4 & 120 & NA & - & 20 \\
\hline
\end{tabular}

\begin{tabular}{|c|c|c|c|c|}
\hline Analysis & $\begin{array}{l}\text { Limit of Detection } \\
\text { (LOD) }\end{array}$ & $\begin{array}{l}\text { Sample volume } \\
(\mathrm{mL})\end{array}$ & $\begin{array}{l}\text { Dilution } \\
\text { Corrected LOD } \\
\text { for Coating } \\
\text { Analysis }\end{array}$ & $\begin{array}{c}\text { LOD for the } \\
\text { Leaching Bath } \\
\text { Solid to Liquid } \\
\text { Ratio of } 131 \\
\mathrm{mg} / \mathrm{L}\end{array}$ \\
\hline HPLC & $1 \mathrm{mg} / \mathrm{L}$ & 1 & $3 \mathrm{mg} / \mathrm{L}$ & $5 \mathrm{mg} / \mathrm{L}^{*}$ \\
\hline IC Anions & $5 \mathrm{mg} / \mathrm{L}$ & 1.5 & $52 \mathrm{mg} / \mathrm{L}$ & $200 \mathrm{mg} / \mathrm{L}$ \\
\hline ICP-OES & $0.5 \mathrm{mg} / \mathrm{L}$ & 5 & $2 \mathrm{mg} / \mathrm{L}$ & $10 \mathrm{mg} / \mathrm{L}$ \\
\hline Gamma Spec & $300 \mathrm{dpm} /$ grams & $\begin{array}{c}30 \mathrm{mg} \text { in glass } \\
\text { vial }\end{array}$ & NA & $N A^{*}$ \\
\hline
\end{tabular}




\subsection{Insoluble Content: Aqua Regia Dissolution}

In order to determine the insoluble content and metal concentration of the solids on the pipe, 30 milligrams of removed solids will be microwave digested. The solids will be added to a solution blend of $\mathrm{HCl}, \mathrm{HF}$ and $\mathrm{HNO}_{3}$. The $\mathrm{HCl}$ will digest the sludge, the $\mathrm{HF}$ will digest the MST and $\mathrm{HNO}_{3}$ will decompose the organics (KTPB). A summary of the analytical technique is shown in Table 2.

\section{Leaching Test}

The purpose of this test is to determine the feasibility of using IW or DWPF recycle to remove the wall deposits. Both the IW and DWPF simulants will be prepared in the lab. Two pipes will be placed in $3 \times 27$ inches cylindrical bath, one in each solution. We believe cylindrical bath may not distort the images (square is an alternative). Each bath will be maintained at $35^{\circ} \mathrm{C}$. The pipes will remain in a vertical position during the leaching. Optical pictures will be taken before and after 3 weeks of exposure. The pictures will be used to evaluate physical appearance changes such as texture and reflectivity (since bare metal reflects light differently from deposit covered pipes). After 3 weeks, we plan to submit solution from each bath for gamma counting and HPLC.

\section{Programmatic Risk and Mitigation}

\begin{tabular}{|l|l|l|}
\hline \multicolumn{1}{|c|}{ Table 4. A list of causes, consequences, and mitigation steps for this task. } \\
\hline \multicolumn{1}{|c|}{ Risk Factor } & \multicolumn{1}{|c|}{ Event } & \multicolumn{1}{c|}{ Mitigation } \\
\hline $\begin{array}{l}\text { Pipe and assembly falls off } \\
\text { and drains the content }\end{array}$ & $\begin{array}{l}\text { Lost of support on the } \\
\text { controller malfunction }\end{array}$ & $\begin{array}{l}\text { Replacement available } \\
\text { leaching bath } \\
\text { the support, add new } \\
\text { solutions and continue. }\end{array}$ \\
\hline $\begin{array}{l}\text { Personnel } \\
\text { Lead investigator }\end{array}$ & $\begin{array}{l}\text { Unavailable due to illness } \\
\text { or } \\
\text { other reasons }\end{array}$ & $\begin{array}{l}\text { Identify alternate and keep } \\
\text { maintain updated of } \\
\text { documentation; provide } \\
\text { periodic updates at team } \\
\text { meetings }\end{array}$ \\
\hline
\end{tabular}




\section{Schedule}

The following schedule shows the approximate milestones for the task. The integrated schedule for the project will contain the official schedule.

Receipt of Thermowell sample

Issue Task Plan

Complete Equipment Preparation

Prepare Recycle and IW simulant

Characterization of Solid Deposit

Completion of leaching Test with IW and DWPF stream

Complete Analyses

Draft Report

Review Report

Issue Report

Dispose of Residues
October 14, 2005

November 3, 2005

November 17, 2005

November 17, 2005

November 29, 2005

December 26, 2005

January 7, 2005

January 22, 2006

January 30, 2006

February 5, 2006

February 13, 2006

\section{Safety}

The task leader will review the safety aspects of the experiments described in this task plan to determine their impact on the safety of the facilities. The review will include evaluation of the checklist forms in the Conduct of Research and Development Manual, WSRC-IM-97-00024, Rev 3. The laboratory notebook will contain a copy of the completed checklist. No new experimental hazards, such as new electrical, significant quantities of combustible, explosive, or corrosive materials, elevated pressures, or elaborate mechanical equipment arise from the planned experiments.

\section{Quality Assurance}

This section of the document details the controls necessary to ensure the quality of the results obtained. Analytical measurements will use routine quality assurance protocols for these well established methods. All applicable instruments (e.g., balances and thermocouples) will conform to the Measurement and Test Equipment (or Measurements, Systems and Equipment for ADS) requirements appropriate for this work. Sample dilutions will occur by mass rather than simply by volume to maximize accuracy. 


\section{Task Quality Assurance (QA) Plan Check List}

Task Technical Plan No: wSRC-TR-2005-00193 Task Title: THE CHARACTERIZATION AND LEACHING OF A THERMOWELL AND CONDUCTIVITY PIPES SAMPLE FROM TANK 48H Listed below are the sections of WSRC QA Manual (1Q). Check the 1Q sections applicable to your task. Also, check procedures WPT implements to control the task. This checklist identifies controls for task activities performed by WPT only. (Form Revised 5/25/2005)

\begin{tabular}{|c|c|c|c|}
\hline $\begin{array}{l}\text { 1.1 WSRC 1Q } \\
\text { SECTION }\end{array}$ & $\begin{array}{l}\text { Applies } \\
\text { To Task }\end{array}$ & 1.1.1 Procedures Implemented by WPT & $\begin{array}{l}\text { Procedure } \\
\text { Used }\end{array}$ \\
\hline \multirow[t]{2}{*}{ Organization } & \multirow{2}{*}{$\begin{array}{l}\mathrm{X} \\
\mathrm{X}\end{array}$} & $\begin{array}{l}\text { 1Q, QAP 1-1, Organization } \\
\text { L1, 1.02, SRTC Organization }\end{array}$ & $\mathrm{X}$ \\
\hline & & 1Q, QAP 1-2, Stop Work & $\mathrm{X}$ \\
\hline \multirow[t]{6}{*}{ QA Program } & \multirow{2}{*}{$\begin{array}{l}\mathrm{X} \\
\mathrm{X} \\
\mathrm{X}\end{array}$} & 1Q, QAP 2-1, Quality Assurance Program* & $\mathrm{X}$ \\
\hline & & $\begin{array}{l}\text { 1Q, QAP 2-2, Personnel Training \& Qual. } \\
\text { L1, 1.32, SRTC Read and Sign/Briefing Program }\end{array}$ & $\mathrm{X}$ \\
\hline & $\begin{array}{l}X \\
X\end{array}$ & $\begin{array}{l}\text { 1Q, QAP 2-3, Control of R\&D Activities* } \\
\text { L1, 7.10, Control of Technical Work }\end{array}$ & $\mathrm{X}$ \\
\hline & \multirow[t]{3}{*}{$\mathrm{X}$} & L1, 7.16, Laboratory Notebooks and Logbooks & $\mathrm{X}$ \\
\hline & & $\begin{array}{l}\text { 1Q, QAP 2-4, Auditor/Lead Auditor Qual. \& Cert. } \\
\text { 1Q, QAP 2-5, Qual. \& Cert. of Independent Insp. } \\
\text { Personnel }\end{array}$ & $\begin{array}{l}\text { NA for WPT } \\
\text { NA for WPT }\end{array}$ \\
\hline & & $\begin{array}{l}\text { 1Q, QAP 2-7 QA Program Req. for Analytical } \\
\text { Measurement Systems }\end{array}$ & \\
\hline Design Control & & $\begin{array}{l}\text { 1Q, QAP 3-1, Design Control } \\
\text { L1, 7.10, Control of Technical Work }\end{array}$ & \\
\hline $\begin{array}{l}\text { Procurement } \\
\text { Document } \\
\text { Control }\end{array}$ & & $\begin{array}{l}\text { 1Q, QAP 4-1, Procurement Document Control } \\
\text { E7, 3.10, Determination of Quality Requirements for } \\
\text { Procured Items } \\
\text { 7B, 3E (for reference only) }\end{array}$ & \\
\hline $\begin{array}{l}\text { Instructions, } \\
\text { Procedures } \\
\text { and Drawings }\end{array}$ & $\mathrm{X}$ & $\begin{array}{l}\text { 1Q, QAP 5-1, Instructions, Procedures, \& Drawings } \\
\text { E7, 2.30, Drawings } \\
\text { L1, 1.01, SRNL Procedure Administration }\end{array}$ & $\mathrm{X}$ \\
\hline Document Control & $\mathrm{X}$ & $\begin{array}{l}\text { 1Q, QAP 6-1, Document Control } \\
\text { 1B, MRP 3.32, Document Control }\end{array}$ & $\mathrm{X}$ \\
\hline \multirow[t]{2}{*}{$\begin{array}{l}\text { Control of } \\
\text { Purchased Items } \\
\text { and Services }\end{array}$} & \multirow[t]{2}{*}{$\mathrm{X}$} & $\begin{array}{l}\text { 1Q, QAP 7-2, Control of Purchased Items \& } \\
\text { Services } \\
\text { 7B \& 3E (for reference only) }\end{array}$ & $\mathrm{X}$ \\
\hline & & $\begin{array}{l}\text { 1Q, QAP 7-3, Com. Grade Item Dedication } \\
\text { E7, 3.46, Replacement Item Evaluation/Com- } \\
\text { mercial Grade Dedication }\end{array}$ & \\
\hline $\begin{array}{l}\text { Identification \& } \\
\text { Control of Items }\end{array}$ & $\mathrm{X}$ & 1Q, QAP 8-1, ID and Control of Items* & $\mathrm{X}$ \\
\hline \multirow{3}{*}{$\begin{array}{l}\text { Control of } \\
\text { Processes }\end{array}$} & & 1Q, QAP 9-1, Control of Processes & NA for WPT \\
\hline & & 1Q, QAP 9-2, Control of Nondestructive Exam. & NA for WPT \\
\hline & & 1Q, QAP 9-3, Control of Welding \& Other Joining Proc. & NA for WPT \\
\hline
\end{tabular}


WSRC-TR-2005-00193

Page 11 of 12

\begin{tabular}{|c|c|c|c|}
\hline & & $\begin{array}{l}\text { 1Q, QAP 9-4, Work Processes } \\
1 \mathrm{Y}, 8.20 \text {, Work Control Procedure }\end{array}$ & \\
\hline Inspection & & $\begin{array}{l}\text { 1Q, QAP } 10-1, \text { Inspection } \\
\text { L1, 8.10, Inspection }\end{array}$ & NA for WPT \\
\hline Test Control & & $\begin{array}{l}\text { 1Q, QAP } 11-1 \text {, Test Control (applies to WPT only for } \\
\text { acceptance testing; R\&D test activities are controlled } \\
\text { by } 1 Q \text {, QAP 2-3) }\end{array}$ & \\
\hline \multirow{3}{*}{$\begin{array}{l}\text { Control of } \\
\text { Measuring \& Test } \\
\text { Equipment }\end{array}$} & \multirow{3}{*}{$\mathrm{X}$} & 1Q, QAP 12-1, Control of Measuring \& Test Equipment & $\mathrm{X}$ \\
\hline & & $\begin{array}{l}\text { 1Q, QAP 12-2, Control of Installed Process } \\
\text { Instrumentation }\end{array}$ & $\mathrm{X}$ \\
\hline & & $\begin{array}{l}\text { 1Q, QAP 12-3, Control \& Calibration of Radiation } \\
\text { Monitoring Equipment }\end{array}$ & \\
\hline $\begin{array}{l}\text { Packaging, } \\
\text { Handling, } \\
\text { Shipping \& } \\
\text { Storage }\end{array}$ & & 1Q, QAP 13-1, Pkg., Handling, Ship. \& Storage* & \\
\hline $\begin{array}{l}\text { Inspection, Test, } \\
\text { and } \\
\text { Operating Status }\end{array}$ & & 1Q, QAP 14-1, Inspection, Test, \& Operating Status* & \\
\hline $\begin{array}{l}\text { Control of } \\
\text { Nonconforming } \\
\text { Items \& Activities }\end{array}$ & $\mathrm{X}$ & 1Q, QAP 15-1, Control of Nonconforming Items* & $\mathrm{X}$ \\
\hline $\begin{array}{l}\text { Corrective Action } \\
\text { System }\end{array}$ & $\mathrm{X}$ & $\begin{array}{l}\text { 1Q, QAP 16-3 Corrective Action Program } \\
\text { 1.01, MP 5.35, Corrective Action Program }\end{array}$ & $\mathrm{X}$ \\
\hline QA Records & $\mathrm{X}$ & $\begin{array}{l}\text { 1Q, QAP 17-1, QA Records Management* } \\
\text { L1, 7.16, Laboratory Notebooks and Logbooks }\end{array}$ & $\mathrm{X}$ \\
\hline \multirow[t]{5}{*}{ Audits } & \multirow[t]{5}{*}{$\mathrm{X}$} & 1Q, QAP 18-2, Surveillance & $\mathrm{X}$ \\
\hline & & 1Q, QAP 18-3, QA External Audits & $\mathrm{X}$ \\
\hline & & $\begin{array}{l}\text { 1Q, QAP 18-4, Management Assessment Program } \\
\text { 12Q, Assessment Manual }\end{array}$ & $\mathrm{X}$ \\
\hline & & 1Q, QAP 18-6, Quality Assurance Internal Audits & \\
\hline & & 1Q, QAP 18-7, Quality Assurance Supplier Surveillance & \\
\hline $\begin{array}{l}\text { Quality } \\
\text { Improvement }\end{array}$ & $\mathrm{X}$ & 1Q, QAP 19-2, Quality Improvement* & $\mathrm{X}$ \\
\hline $\begin{array}{l}\text { Software Quality } \\
\text { Assurance }\end{array}$ & & $\begin{array}{l}\text { 1Q, QAP 20-1, Software QA } \\
\text { L1, 8.20, Software Management \& QA }\end{array}$ & \\
\hline $\begin{array}{l}\text { Environmental } \\
Q A\end{array}$ & & $\begin{array}{l}\text { 1Q, QAP 21-1, Quality Assurance Requirements for } \\
\text { the Collection and Eval. of Environmental Data }\end{array}$ & NA for WPT \\
\hline
\end{tabular}

EXCEPTIONS/ADDITIONS-PROCEDURES IDENTIFIED ON THE CHECKLIST WITH AN ASTERISK $\left(^{*}\right)$ ARE SUPPLEMENTED BY A SRNL CLARIFICATION IN L1, 8.02, "SRTC QA PROGRAM CLARIFICATIONS". WSRCIM-2002-00011, “TECHNICAL REPORT DESIGN CHECK GUIDELINES,” WILL BE USED TO HELP ENSURE THE QUALITY AND CONSISTENCY OF THE TECHNICAL REVIEWER PROCESS FOR TECHNICAL REPORTS PRODUCED BY SRNL WASTE TREATMENT TECHNOLOGY. ASTM D3483-05, "STANDARD TEST METHODS FOR ACCUMUlated DEPOSITION IN A STEAM GENERATOR TUBE” 
WSRC-TR-2005-00193

Page 12 of 12

\section{References:}

1 CBU-PIT-2005-00004, Rev 0, Volume and Content Estimate of Deposits on Tank 48H Internal Structures, W. B. Dean, January 12, 2005.

2 WSRC-TR-2000-00253, Rev 0, Tank 49 Disposition Plan, K. B. Martin, T. B. Peters, et al, July 20, 2000.

3 R. F. Calta, “Tank 48H Disposition: Residue Sample Retrieval and Analysis Plan,” CBUSPT-2005-00145, September, 2005.

4 R. C. Fowler, “Tank 48 Disposition Project Flowsheet for Aggregation Strategy 0.2 Ci/gal Cesium Max Feed,” CBU-PIT-2004-00012, February 4, 2005.

5 ASTM D3483-05, "Standard Test Methods for Accumulated Deposition in a Steam Generator Tube" 